\title{
An overview of novel technologies to valorise coke oven gas surplus
}

\author{
José M. Bermúdez ${ }^{\mathrm{a}}$, Ana Arenillas ${ }^{\mathrm{a}}$, Rafael Luque ${ }^{\mathrm{b}}, \mathrm{J}_{\text {Angel Menéndez }}^{\mathrm{a} *}$ \\ ${ }^{a}$ Instituto Nacional del Carbón, CSIC, Aparatado 73, 33080 Oviedo, Spain \\ ${ }^{\mathrm{b}}$ Departamento de Química Orgánica, Universidad de Córdoba, Campus de Excelencia \\ Agroalimentario ceiA3, Edificio Marie Curie (C-3), Ctra. Nnal IV-A, Km 396, E- \\ 14014, Córdoba, Spain \\ * Corresponding authors. E-mail address: angelmd@incar.csic.es \\ Tel.: +34 985 18972; Fax: +34 985297672
}

\begin{abstract}
The steelmaking industry is the largest energy consuming manufacturing sector in the world and is responsible for $5-7 \%$ of anthropogenic $\mathrm{CO}_{2}$ emissions. It is therefore necessary to increase energy efficiency and reduce greenhouse gases emissions in these industries. COG, a by-product of coking plants, is one of the key ways to achieve these goals. COG, which is used as fuel in different processes of the steelmaking plants, is a $\mathrm{H}_{2}$-rich gas with a high energetic potential. However, there is a significant surplus that usually is burnt away in torches, and even directly emitted into the air. With the aim of tackling this wasting of resources and energy inefficiency, several alternatives have been proposed during recent years. In the present work, these alternatives are reviewed and their main advantages and drawbacks are discussed.
\end{abstract}

\section{Keywords}

Coke oven gas, Hydrogen, Reforming, Synthesis gas, Methanol, Energy recovery 


\section{Contents}

1. Introduction

2. Hydrogen Separation

2.1. Pressure swing adsorption

2.2. Membrane separation

2.3. Other hydrogen separation technologies

3. Synthesis gas production

3.1. Steam reforming

3.2. Dry reforming

3.3. Partial oxidation

3.4. Methanol production

4. Other technologies

5. Summary and conclusions

Acknowledgements

References 


\section{Introduction}

The steel industry is the largest energy consuming manufacturing sector worldwide $[1,2]$. Consequently, their associated $\mathrm{CO}_{2}$ emissions account for about 5-7 \% of the total anthropogenic carbon dioxide emissions $[1,2]$. Taking into account that steel production is expected to increase during the next few decades, a significant increase in energy consumption as well as $\mathrm{CO}_{2}$ emissions are also expected to follow [1-3]. The steel industry has been committed to sustainability since 1960's, and in some countries (e.g. France) these have reduced $\mathrm{CO}_{2}$ emissions and energy consumption by $60 \%$ and $50 \%$, respectively, per tonne of steel produced [1]. However, manufacturing processes of the steel industry have reached high levels of efficiency and are very close to their physical limits in terms of carbon use [1]. Energy and greenhouse gases (GHG) emissions concerns have created the need to seek for alternative ways to improve the energey efficiency of steel plants decreasing (if possible) at the same time carbon dioxide emissions $[1,2,4-6]$. An interesting example of initiatives related to this concern in the iron and steel industry is the program COURSE50 ("CO2 Ultimate Reduction in the Steelmaking Process by Innovative Technologies for Cool Earth 50"). This program is currently being developed in Japan to find alternative uses for blast furnaces and coke oven gases in order to reduce carbon dioxide emissions and improve energy efficiency in Japanese steel industries [6].

Coke oven gas (COG) is a point of high interest to enhance energy efficiency and reduce GHG emissions in the steel industry $[2,3,5,6]$. COG is a by-product of coal carbonisation to coke which is co-generated in the coking process [7]. In spite of the reduction of coke consumption in the blast furnace (and therefore COG production), during the past few decades, blast furnaces cannot operate without coke which implies COG will continue to be produced in large quantities in the future [3].

COG, has a very complex composition after leaving the coke oven. Firstly, the gas is cooled down to separate tars to subsequently undergo different scrubbing processes to eliminate $\mathrm{NH}_{3}, \mathrm{H}_{2} \mathrm{~S}$ and BTX [3]. After these conditioning stages, cold COG comprises $\mathrm{H}_{2}(\sim 55-60 \%), \mathrm{CH}_{4}(\sim 23-27 \%), \mathrm{CO}(\sim 5-8 \%), \mathrm{N}_{2}(\sim 3-6 \%), \mathrm{CO}_{2}$ (less than $\left.2 \%\right)$ along with other hydrocarbons in small proportions. Currently $20-40 \%$ of COG produced is normally utilised as fuel in the actual coke ovens [8-10]. The remaining COG generated 
is generally employed in alternative processes of the steel mills [3,7] but most surplus is currently burnt off in torches and even in some cases directly emitted to the air $[10,11]$. These vary due to the highly dynamic nature of the steel-making process [8].

In addition, COG approximately accounts for $18 \%$ of the energy output of a coking plant due to its large low calorific value, which varies from 17 to $18 \mathrm{MJ} / \mathrm{m}^{3}$ [3]. Both COG energetic properties and production excess lead to large GHG emissions, energy inefficiency and most importantly a significant environmental impact which in turn is also reflected in a clearly improvable economic efficiency $[3,4,12]$. As an example of this inefficiency, U.S. Steel Corp. has been able to save over 6 million dollars annually by using COG as fuel in blast furnaces [8].

During past few decades, various alternatives to valorise COG have been proposed, including its use for energy production, a direct utilisation in the blast furnace to produce "pig iron" or gas treatment for the production of chemicals and fuels.

This work is aimed to provide an overview of some of the most promising and challenging technologies from the research viewpoint. Proposed alternatives can be grouped into three main categories: hydrogen separation, synthesis gas production and other technologies.

Each of these alternatives requires different preconditioning stages as the presence of some COG components (especially $\mathrm{H}_{2} \mathrm{~S}$ and $\mathrm{NH}_{3}$ ) may be highly damaging for the processes $[3,4,13]$. This will be described in detailed in each section.

\section{Hydrogen Separation}

Hydrogen is the main and most valuable component in COG, which is the reason why COG has been proposed as an alternative hydrogen source. Pressure swing adsorption and membrane separation have been the two main technologies proposed for this purpose, although other possibilities have also been investigated including hydrate formation and cryogenic separation. 


\subsection{Pressure swing adsorption}

The leading technology to efficiently separate hydrogen from COG is pressure swing adsorption (PSA) [6,7,11,14-23]. This technology is a low-cost, low-energy and highly efficient gas separation process [24]. PSA processes employ several parallel units that operate in consecutive steps. Figure 1 shows a schematic representation of the operating steps in a system comprising two adsorption beds. The process commences with an adsorption step, in which the crude gas flows through a PSA unit filled with adsorbent materials at the highest operation pressure. The adsorbable substances are retained by the adsorbents and the rest of the gas leaves the unit. After a period of time, the adsorbent saturates and the operation is stopped. At this point, the adsorbent needs to be regenerated at the lowest pressure, so the unit needs to be depressurised. The depressurisation cycle is terminated by counter-flow expansion down to the lowest pressure, called dump step. The adsorber is regenerated with a gas stream which purges all the adsorbed impurities. Finally, the adsorber is brought back to high pressure conditions to resume adsorption. These cycles operate at constant temperature, requiring no heating or cooling steps [24,25]. Different adsorbent materials are utilised for hydrogen recovery, most commonly carbonaceous materials, alumina oxides or zeolites $[16,17,19,24]$.

Other components in $\mathrm{COG}$ (e.g. higher hydrocarbons, $\mathrm{H}_{2} \mathrm{~S}$ or $\mathrm{NH}_{3}$ ) have to be removed before reaching the adsorption bed owing to issues associated to bed saturation (as they cannot be desorbed by decreasing the pressure in the systems) $[3,18]$. For this reason, COG needs to undergo complete preconditioning prior to its utilisation in PSA processes.

Two different streams, namely a $\mathrm{H}_{2}$-rich stream and a highly concentrated $\mathrm{CH}_{4}$ gas, are generally obtained in PSA $\mathrm{H}_{2}$ separation from COG. The methane-enriched stream can be considered as a substitute of natural gas (SNG), with the possibility to be employed as fuel in various plant processes in a similar way to COG. However, the loss of energetic power due to $\mathrm{H}_{2}$ separation from $\mathrm{COG}$ needs to be compensated by other fuels if this methane-rich stream is used as fuel $[7,15,16]$. Other technologies should be obviously used in combination with PSA to achieve an optimum valorisation of COG. 


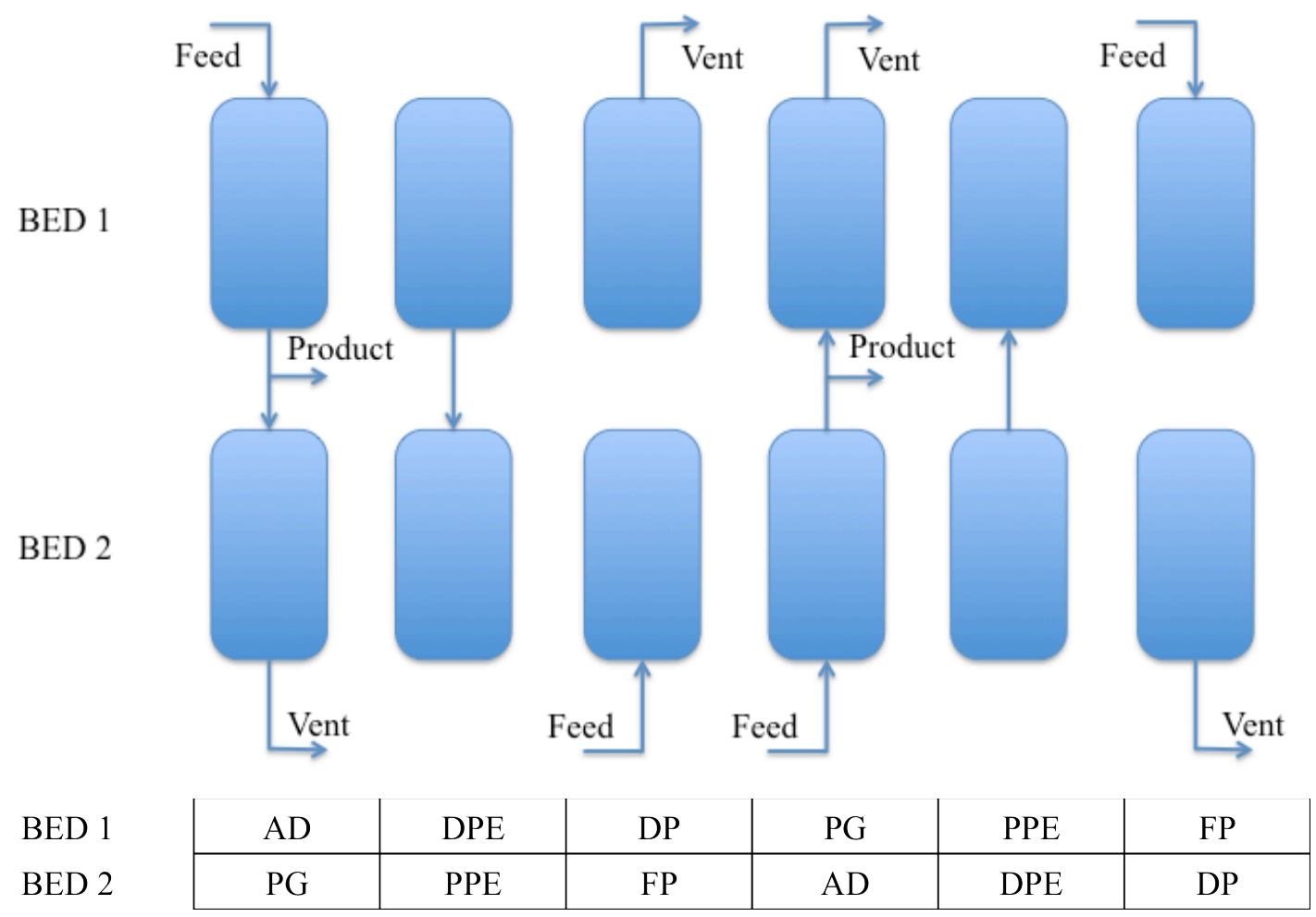

Fig. 1. Scheme of the operation steps of a pressure swing adsorption system composed of two adsorption beds (AD, adsorption; DPE, depressurizing pressure equalization; DP, depressurization; PG, purge; PPE, depressurizing pressure equalization; FP, feed pressurization). Adapted from [20]

Most studies published in the field of PSA have considered simple mixtures with two or three components, which cannot possibly have a similar behaviour to that of COG $[18,19]$. Yang and Lee [18] studied the dynamics of the system and proposed a mathematical model of PSA adsorption to recover $\mathrm{H}_{2}$ from $\mathrm{COG}$ using a layered bed of activated carbon and zeolites. These authors claimed that the composition of the bed is a key parameter in the process, since the employed materials can influence the concentration of the major impurity in the final stream. In the particular case of a layered bed of activated carbon and zeolites, it is necessary to establish the optimum carbon ratio (defined as the ratio of activated carbon layer length to the bed length) $[18,21]$. Another interesting conclusion of these studies is that, although $\mathrm{N}_{2}$ is a minor impurity in COG, it can play an important role in the process, giving rise to different breakthrough times for the rest of the components fed into the PSA column [21,22]. Ahn et al. [20] included a backfill step in the PSA process and found that this additional 
step increased $\mathrm{H}_{2}$ purity in the final stream at the expense of decreasing $\mathrm{H}_{2}$ recovery. However, $\mathrm{H}_{2}$ purities higher than $99.99 \%$ were very difficult to achieve.

Further studies beyond fundamental research have also been conducted to ascertain a plausible implementation of this technology at industrial level. Joseck et al. [7] explored the possibility of $\mathrm{H}_{2} / \mathrm{COG}$ separation by means of PSA technology, aiming to valorise COG for fuel cell vehicles (FCVs). The study was carried out in the Rust Belt (Midwest-Northeast US area with an important network of coking and steel plants) and showed that $\mathrm{H}_{2}$ obtained from such a large concentration of plants could fuel ca. 1.7 million FCVs. The economics of the project however need to be thoroughly examined but the project can in principle offer a significant potential in terms of energy savings and reduction of GHG emissions.. A similar study conducted by Hwang and Chang [23] assessed the possibility to use hydrogen from different sources in fuel cell scooters in Taiwan. Life-cycle Analysis studies revealed that FC scooters fueled with hydrogen from COG accounted for the most efficient technology, resulting in remarkably reduced GHG emissions together with a improved energy efficiencies.

\subsection{Membrane separation}

Another recently proposed technology for hydrogen recovery from COG is membrane separation [11]. Membrane gas separation is a pressure-driven process which entails several advantages compared to other technologies (i.e. easy operation, low capital and operating costs and low-energy requirements) [26]. In a membrane separation process, a gaseous mixture at high pressure is forced to pass through the surface of a membrane which is selectively permeable to one or more of the gas components. As a result, the permeate (stream obtained after it has passed through the membrane) can be enriched in these components while the retentate (stream that does not pass through the membrane) is therefore enriched in the rest of the components. A basic scheme of the process is shown in Figure 2 [25,27]. Shen et al. reported that a $\mathrm{H}_{2}$-rich stream $(>95 \%$ maximum $\mathrm{H}_{2}$ concentration)and a $\mathrm{CH}_{4}$-rich stream $\left(70 \%\right.$ maximum $\mathrm{CH}_{4}$ concentration $)$ could both be obtained using an organic membrane [11]. However, membrane technologies have been mostly applied in the form of membrane reactors for to syngas production processes, to increase conversions and selectivities, as detailed in Section 3. 


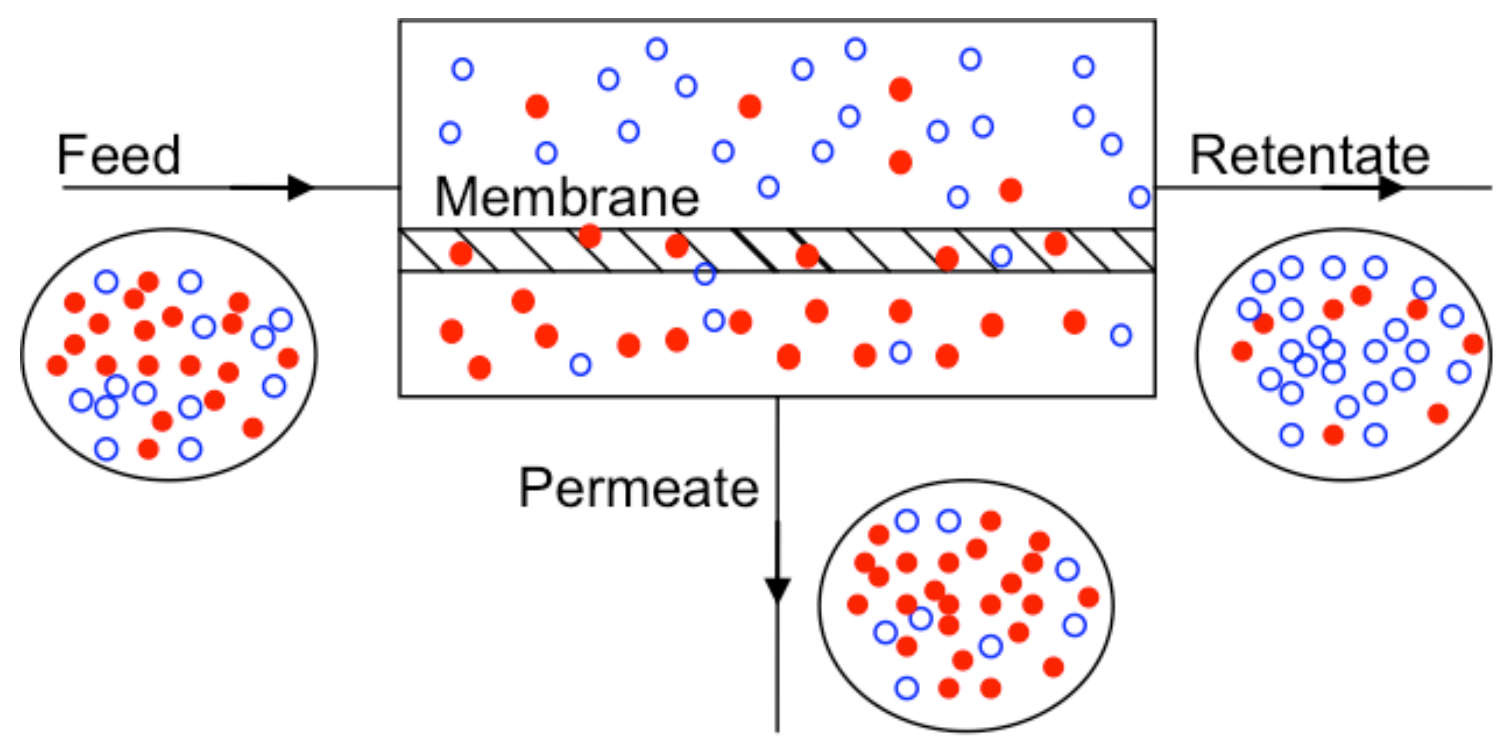

Fig. 2. Scheme of the operation of a separation membrane system

\subsection{Other technologies}

Other hydrogen separation technologies including cryogenic separation [28] and hydrate formation [29] have been proposed as alternatives to PSA and membrane separation for COG valorisation. Cryogenic separation processes proposed by Chang et al. [28] comprising four steps, namely 1) separation of heavier compounds (hydrocarbons like ethylene and propane) 2) methane separation 3) $\mathrm{O}_{2}-\mathrm{CO}-\mathrm{N}_{2}$ separation and 4) eventual separation-liquefaction of hydrogen. While the principles of the proposed methodology are sound, this technology is still in its infancy and needs to undergo further developments and studies prior to a potential implementation at industrial scale.

Comparatively, hydrate separation has the advantage of being a simple process which can be operated at mild conditions. Hydrates are non-stoichiometric crystalline compounds formed by small molecules of gas and water under certain temperature and pressure conditions $[29,30]$. A maximum $\mathrm{H}_{2}$ concentration of $80 \mathrm{vol}$. \% in the final product has been obtained using this hydrate methodology, with recovering yields in the $72-90 \%$ range [29]. Apart from a low hydrogen concentration, the technology has associated drawbacks including the need to use additives such as tetrahydrofuran (to decrease pressure operation) or sodium dodecyl sulfate (to increase reaction rates). The proposed technology has promising prospects of application in hydrogen recovery from 
COG but it is currently at a very low stage of development compared to alternative available technologies.

\section{Synthesis gas production}

Synthesis gas (syngas) is a $\mathrm{H}_{2}$ and $\mathrm{CO}$ enriched mixture utilised as raw material for the large scale production of hydrogen and a wide variety of organic products and fuels [31]. Syngas has been extensively produced from natural gas and oil, but the limited supply of fossil fuels and concerns on climate change and GHG emissions have intensified the search for alternative processes of syngas production including biomass gasification [32], biogas reforming [33] and the thermal upgrading of COG [5,9,10,3455]. The main thermal upgrading technologies studied for COG valorisation include steam [34-39,43-45,49] and dry reforming [9,40-42,46-48] as well as partial oxidation [10, 50-55]. Turpeinen et al. [56] reported an interesting thermodynamic analysis of COG conversion into hydrogen using these three different technologies as compared to other potential hydrogen sources (e.g. natural gas, biogas and refinery gas). This study conveys an idea of the remarkable potential of COG as a source of syngas, particularly related to the use of the produced syngas for hydrogen generation. COG is clearly the best source in terms of energy consumption and $\mathrm{CO} 2$ emissions when steam and especially dry reforming is conducted. Partial oxidation of COG still gives rise to the lowest $\mathrm{CO}_{2}$ emissions but syngas production from natural and refinery gas is less energy consuming [56].

All proposed methodologies employ a catalyst which can be severely poisoned by the presence of some COG components. For this reason, a cleaning process (e.g. scrubbers or absorbers) is required prior to reaction $[3,57,58]$. In the case of dry reforming, the development of the SPARG process (where the catalyst is partially poisoned with $\mathrm{H}_{2} \mathrm{~S}$ to avoid coke formation) may avoid the need to remove $\mathrm{H}_{2} \mathrm{~S}[59,60]$.

\subsection{Steam reforming}

The steam reforming of methane (Reaction 1) is currently the main process for hydrogen or syngas production. This process involves the heterogeneously catalysed reaction of methane and steam to obtain a syngas with high $\mathrm{H}_{2} / \mathrm{CO}$ ratio (theoretically 
3/1). Nearly all metals from Group VIII have been investigated as supported on various supports. Ni has attracted most interest due to its greater availability and lower cost compared to the other metals. Normally, the reaction takes places in tubular reactors, the catalyst being placed inside the tubes. The process is carried out at high temperatures $\left(700-1000{ }^{\circ} \mathrm{C}\right)$ as the steam reforming of methane is a highly endothermic reaction. The pressure is normally mild (20-30 bar), although the reaction produces an increase in the net number of moles and, therefore, high pressures lead to a reduction in the conversion of the systems. This is assumed because the products are normally used in processes at high pressure and it is cheaper to compress the methane and the steam than the synthesis gas produced. Moreover, carrying out the process under pressure allows smaller reactors to be used [57,61-63].

$\mathrm{CH}_{4}+\mathrm{H}_{2} \mathrm{O} \leftrightarrow 3 \mathrm{H}_{2}+\mathrm{CO}$

(Reaction 1)

Side reactions may take place between the different species present in COG. This may affect the selectivity of the process and the final product composition. Some examples of side reactions include water gas shift (WGS), reverse WGS chemistries (Reaction 2) and dry reforming processes (Reaction 3), as well as $\mathrm{CH}_{4}$ decomposition (Reaction 4) and the Boudouard equilibrium (Reaction 5).

$\mathrm{H}_{2} \mathrm{O}+\mathrm{CO} \leftrightarrow \mathrm{H}_{2}+\mathrm{CO}_{2}$

(Reaction 2)

$\mathrm{CH}_{4}+\mathrm{CO}_{2} \leftrightarrow 2 \mathrm{H}_{2}+2 \mathrm{CO}$

(Reaction 3)

$\mathrm{CH}_{4} \rightarrow 2 \mathrm{H}_{2}+\mathrm{C}$

(Reaction 4)

$\mathrm{C}+\mathrm{CO}_{2} \leftrightarrow 2 \mathrm{CO}$

(Reaction 5)

One of the most critical factors in the steam reforming of methane is $\mathrm{H}_{2} \mathrm{O} / \mathrm{CH}_{4}$ ratio. Steam is generally injected in excess over the stoichiometric value of the reaction $\left(\mathrm{H}_{2} \mathrm{O} / \mathrm{CH}_{4}>1\right)$ as it prevents catalyst deactivation caused by carbon deposits on the catalyst $[57,61]$. Excess steam is used to prevent the formation of coke, while additional heat is needed, so a lower $\mathrm{H}_{2} \mathrm{O} / \mathrm{CH}_{4}$ ratio is desired to improve the energy efficiency of 
the process. In the case of the steam reforming of $\mathrm{COG}$, this ratio may differ from that used in the steam reforming of methane, as the presence of $\mathrm{H}_{2}, \mathrm{CO}_{2}$ and $\mathrm{CO}$ in $\mathrm{COG}$ influences the equilibriums of the different reactions involved in the process. Zhang et al. $[38,45]$ reported that the thermodynamically permissible $\mathrm{H}_{2} \mathrm{O} / \mathrm{CH}_{4}$ value should be in 1.1-1.3 range, at temperatures between $950-1000^{\circ} \mathrm{C}$. A kinetic model for the steam reforming of COG was also proposed taking into consideration the combination of steam and dry reforming (due to the presence of carbon dioxide in COG). Results revealed that both reactions were of first order from methane, steam and carbon dioxide, with kinetic parameters shown in Table 1. Changing the $\mathrm{H}_{2} \mathrm{O} / \mathrm{CH}_{4}$ ratio to 1.0 was also found to be possible using a $\mathrm{NiO} / \mathrm{MgO}$ catalyst due to excellent coking resistance of the catalyst [43].

Table 1. Kinetic parameters of the steam reforming of COG [38]

\begin{tabular}{ccc}
\hline & $\mathrm{A}$ & $\mathrm{E}$ a $(\mathrm{J} / \mathrm{mol})$ \\
\hline $\begin{array}{c}\text { Steam reforming rate } \\
\left(\mathrm{K}_{\mathrm{SR}}\right)\end{array}$ & $4.56 \cdot 10^{9}$ & 21373.4 \\
$\begin{array}{c}\text { Dry reforming rate } \\
\left(\mathrm{K}_{\mathrm{DR}}\right)\end{array}$ & $8.06 \cdot 10^{8}$ & 20843.7 \\
\hline Kinetic equation & $r_{C H_{4}}=A_{S R} \cdot \exp \left(-\frac{E_{a S R}}{T}\right) \cdot C_{C H_{4}} \cdot C_{H_{2} O}+A_{D R} \cdot \exp \left(-\frac{E_{a D R}}{T}\right) \cdot C_{C H_{4}} \cdot C_{C O_{2}}$ \\
\hline
\end{tabular}

The use of hot COG (no conditioning processes prior to leaving the coke oven) in the steam reforming process has been widely proposed to reform methane as well as the tarry components, taking advantage of the high temperatures of the gas to promote the desired reactions [34-37,39,44,49]. As hot COG contains ca. 10-15\% steam, the energy efficiency and cost of the process can be improved as lower quantities of steam need to be injected in the system. Tars usually account for $30 \mathrm{wt} \%$ of hot COG, the main components being naphthalene, benzene, pyrene and toluene [34,35]. These species compete with each other and with methane in steam reforming processes, especially naphthalene (the only component which reacts at temperatures below $750{ }^{\circ} \mathrm{C}$ while at higher temperatures the other compounds react once naphthalene has been completely converted) [34]. Steam reforming of hot COG can be carried out in the presence or 
absence of catalysts, but the presence of a catalyst significantly improves the results obtained. The main disadvantage of using hot $\mathrm{COG}$ is related to the lower ratio $\mathrm{H} / \mathrm{C}$ obtained as compared to conditioned COG which in turn leads to a very important production of carbonaceous deposits of different nature in the system (i.e. well-ordered graphite, non-oriented carbon forms, carbon filaments and metal carbides) depending on the working temperatures [49]. The generation of carbonaceous deposits also increases the deactivation rate of the catalyst. The presence of hydrogen, an adequate load of active metal as well as an appropriate steam/carbon ratio could contribute to reduce such deactivation rate $[39,44,49]$. The presence of $\mathrm{H}_{2} \mathrm{~S}$ is also highly undesirable due to its poisoning effects on catalysts (e.g. Ni) but generally this deactivation effect is low and the catalyst can easily be regenerated [34,49]. Remarkably, this technology can potentially generate 3-5 times more $\mathrm{H}_{2}$ to that of the COG before undergoing the reforming process, making the steam reforming of hot COG one of the most promising alternatives for $\mathrm{H}_{2}$ production from $\mathrm{COG}$. Reports may indicate that hydrogen can be produced by combining steam reforming and partial oxidation of hot COG, reducing by $30 \%$ production costs as compared to PSA mediated direct hydrogen separation from the COG [37].

\subsection{Dry reforming}

$\mathrm{CO}_{2}$ reforming or dry reforming of methane (Reaction 3) has been widely proposed as an alternative process to steam reforming of methane [64-68]. The increasing interest in this process is based on the lower energy requirements compared to steam reforming together with the consumption of two commonly extended greenhouse gases such as $\mathrm{CH}_{4}$ and $\mathrm{CO}_{2}$, with an eventual generation of highly valuable products. $\mathrm{CO}_{2}$ reforming also allows the production of a low $\mathrm{H}_{2} / \mathrm{CO}$ ratio syngas (theoretically $1 / 1$, although the presence of side reactions, such as reverse WGS slightly reduces it), which is suitable for the production of higher hydrocarbons and oxygenated derivatives $[31,66]$.

$$
\mathrm{CH}_{4}+\mathrm{CO}_{2} \leftrightarrow 2 \mathrm{H}_{2}+2 \mathrm{CO}
$$

As in the case of steam reforming, dry reforming must be carried out in the presence of a catalyst. Once again, Ni has been the most commonly metal utilised as catalyst in dry reforming chemistries, but the drawback to this process is the intense formation of 
carbonaceous deposits which leads to a rapid catalyst deactivation. This drawback should be addressed prior to technology implementation at industrial scale. Consequently research efforts related to dry reforming of methane have been focused on the development of commercial catalysts able to achieve high and stable conversions, being at the same time resistant to deactivation [64,65,69-71]. To date, only two processes based on methane dry reforming have been industrially implemented: the SPARG process $[59,60]$ and the CALCOR process for CO production [72].

The SPARG process could be especially interesting in the application of dry reforming methodologies to COG. This technology is based on the addition of $\mathrm{H}_{2} \mathrm{~S}$ to the process stream which leads to a partial poisoning of the catalyst but prevents at the same time the formation of carbonaceous deposits in the active centers of the catalyst, keeping high conversions of $\mathrm{CH}_{4}$ and $\mathrm{CO}_{2}$ in the systems [59,60]. In this way, the previous scrubbing step required to remove $\mathrm{H}_{2} \mathrm{~S}$ from $\mathrm{COG}$ can be eliminated in the conditioning stages, improving the economics of COG valorisation.

Until now, the application of dry reforming to COG has received less attention than steam reforming or partial oxidation [9,40-42,46-48]. Nevertheless, results reported in these works are encouraging, pointing to a potentially optimum way to transform COG into syngas with a close to optimum $\mathrm{H}_{2} / \mathrm{CO}=2$ ratio to be employed in Fischer-Tropsch (FT) synthesis of chemicals as well as in methanol production. Comparatively, steam reforming of COG gives rise to $\mathrm{H}_{2} / \mathrm{CO}$ ratios that are considerably higher than 3 (ratio obtained with methane) [47]. In the case of partial oxidation, the $\mathrm{H}_{2} / \mathrm{CO}$ ratio obtained with methane is ca. 2, so that an expected $\mathrm{H}_{2} / \mathrm{CO}$ ratio of $2.5-3$ will be likely to be the case in COG partial oxidation due to its hydrogen content. These values are not close to the optimal requirements for FT processes and methanol synthesis [47] and entail the addition of further conditioning stages which are not required in the case of dry reforming of COG $[9,40-42,47]$.

Side reactions may also influence the theoretical results in COG dry reforming as observed in other processes. In this case, the reverse WGS (reaction 2) is the most critical. acting as a step in the process, rather than as a side reaction [40], leading to two different alternative pathways: 
1. Direct dry reforming: methane is decomposed into hydrogen and carbon through reaction 4 and then carbon is gasified to $\mathrm{CO}$ through the Boudouard equilibrium (reaction 5).

$\mathrm{CH}_{4} \rightarrow 2 \mathrm{H}_{2}+\mathrm{C}$

(Reaction 4)

$\mathrm{C}+\mathrm{CO}_{2} \leftrightarrow 2 \mathrm{CO}$

(Reaction 5)

2. Reverse WGS followed by steam reforming (SR): the large amount of hydrogen contained in COG promotes the RWGS reaction (reaction 2), producing water which subsequently reacts with methane (steam reforming) to generate $\mathrm{CO}$ and $\mathrm{H}_{2}$ (reaction 1).

$\mathrm{H}_{2}+\mathrm{CO}_{2} \leftrightarrow \mathrm{H}_{2} \mathrm{O}+\mathrm{CO}$

(Reaction 2)

$\mathrm{CH}_{4}+\mathrm{H}_{2} \mathrm{O} \leftrightarrow 3 \mathrm{H}_{2}+\mathrm{CO}$

(Reaction 1)

The direct dry reforming generates carbon as by-product as $\mathrm{CO}_{2}$ is not generally able to convert all carbon produced to $\mathrm{CO}$, resulting in the deactivation of the catalyst $[9,41,47]$. Comparatively, the RWGS+SR pathway generates water as by-product which influences $\mathrm{H}_{2}$ selectivity (reduced) and consequently $\mathrm{H}_{2} / \mathrm{CO}$ ratios differ from 2 [9,40$42,47]$.

Three different types of catalysts have been studied for dry reforming processes. These include carbonaceous materials, Ni supported catalysts and mixtures of both catalysts. Table 2 summarises the best conversion and selectivity results obtained for the different literature reported catalysts.

The most interesting results have been obtained with mixtures of activated carbon and $\mathrm{Ni} / \mathrm{Al}_{2} \mathrm{O}_{3}$ catalysts, since these have been reported to have a synergetic effect [40], which was previously observed in the dry reforming of methane [73]. Interestingly, this synergism that leads to higher activities and selectivities was more noticeable in COG dry reforming [40], with catalysts also being more stable (in terms of BET surface area 
reduction) and generating less water [40]. CO was found to have a negative influence on such synergetic effect, pointing out that these catalysts will be more efficient in processing COG of low CO content.

Table 2. Conversions and selectivities of the catalysts studied in the dry reforming of COG.

\begin{tabular}{|c|c|c|c|c|c|c|}
\hline \multirow{2}{*}{ Catalyst } & \multirow{2}{*}{$\begin{array}{c}\text { Temperature } \\
\left({ }^{\circ} \mathrm{C}\right)\end{array}$} & \multirow{2}{*}{$\begin{array}{l}\text { VHSV } \\
(\mathrm{L} / \mathrm{g} \cdot \mathrm{h})\end{array}$} & \multicolumn{2}{|c|}{ Conversions (\%) } & \multirow{2}{*}{$\begin{array}{c}\text { Selectivity } \\
(\%)\end{array}$} & \multirow[t]{2}{*}{ Ref. } \\
\hline & & & $\mathrm{CH}_{4}$ & $\mathrm{CO}_{2}$ & & \\
\hline Charcoal & 1000 & 7.5 & 70 & 90 & n.d. & [48] \\
\hline Activated carbon & 1000 & 0.75 & 82 & 95 & $90-100$ & [42] \\
\hline $\mathrm{Ni} / \mathrm{SiO}_{2}$ & 800 & 30 & 75 & 80 & 100 & [9] \\
\hline $\mathrm{Ni} / \mathrm{Al}_{2} \mathrm{O}_{3}$ & 900 & 9 & 90 & 95 & 94 & [41] \\
\hline $\begin{array}{l}\mathrm{Ni} / \mathrm{Al}_{2} \mathrm{O}_{3}(67 \%) \\
\text { Activated Carbon }(33 \%)\end{array}$ & 800 & 3,75 & 85 & 93 & 85 & [40] \\
\hline
\end{tabular}

\subsection{Partial Oxidation}

The partial oxidation of methane (Reaction 6) is a mildly exothermic reaction which yields a syngas with an intermediate $\mathrm{H}_{2} / \mathrm{CO}$ ratio between those obtained with steam and dry reforming [74].

$\mathrm{CH}_{4}+1 / 2 \mathrm{O}_{2} \leftrightarrow 2 \mathrm{H}_{2}+\mathrm{CO}$

(reaction 6)

In this case, side reactions (Reactions 7 and 8) may also affect the process, changing the $\mathrm{H}_{2} / \mathrm{CO}$ ratio and reducing its selectivity and efficiency [75].

$\mathrm{CH}_{4}+2 \mathrm{O}_{2} \leftrightarrow 2 \mathrm{H}_{2} \mathrm{O}+\mathrm{CO}_{2}$ (reaction 7)

$\mathrm{CH}_{4}+\mathrm{O}_{2} \leftrightarrow 2 \mathrm{H}_{2}+\mathrm{CO}_{2}$ (reaction 8)

The partial oxidation of methane can be carried out in two different ways: non catalytic and catalytic [76]. The non-catalytic method is an established industrial process which 
operates at high temperatures $\left(>1100^{\circ} \mathrm{C}\right)$ and mild pressures $(50-70 \mathrm{~atm}$, mainly due to the high pressure downstream process, as in the case of steam reforming) and which requires very complex equipment. This normally makes the process even less energy efficient to that of methane steam reforming $[62,74,76,77]$.

The catalytic method has a long history (like steam reforming) but has attracted significantly less attention until the past decade. However, its importance will most probably increase during the next few years due to several advantages $[76,77]$ :

- It is a mildly exothermic process. This will increase the energetic efficiency of the process in addition to the lower operating temperatures needed due to the use of catalyst $\left(750-1000^{\circ} \mathrm{C}\right)$,. This is probably the most important advantage of the partial oxidation of methane.

- The final $\mathrm{H}_{2} / \mathrm{CO}$ ratio is generally 2 , that required for methanol production and FT processes. However, this advantage disappears in COG valorisation practises if hydrogen contained in COG is not previously removed (otherwise, the final $\mathrm{H}_{2} / \mathrm{CO}$ ratio will exceed 2, making it less suitable than in the case of the dry reforming for the synthesis of chemicals such us methanol or dimethyl ether [9]).

- Product gases have a very low $\mathrm{CO}_{2}$ concentration, which often needs to be removed prior to the use of syngas in downstream processes.

- Reaction rates are higher compared to those of steam or dry reforming under otherwise identical operating conditions, giving rise to a faster process..

Most research efforts in the field of partial oxidation have been focused on the development of appropriate catalysts for the process, that overcome drawbacks including carbon deposition or loss of active compound during the reaction $[75,77]$. Three main types of catalysts have been proposed based on transition metals (nickel, cobalt and iron), and noble metal supported catalysts as well as transition metal carbide catalysts $[75,77]$. Due to their lower price and wider availability, Ni, Co and Fe, have been the focus of most studies in spite of the improved resistance to deactivation of noble metal supported catalysts. Nickel has been reported to be highly active and selective for syngas production, but it also efficiently catalyses carbon formation. The use of this particular type of catalyst requires $\mathrm{O} 2$ excess working conditions to work 
with an excess of $\mathrm{O} 2$ to reduce carbon formation. Modification of the support has been reported to improve the stability of the catalyst, but its deactivation is unavoidable with time due to a reduction in the surface area of nickel and carbon deposition. The addition of $\mathrm{Co}$ and $\mathrm{Fe}$ has been reported to enhance the resistance of the catalyst to deactivation. Iron addition stabilises nickel, as compared to a reduction in carbon formation strongly promoted by cobalt addition (which makes possible to work at lower temperatures in Co-promoted catalysts) [77].

Reports focusing on the application of partial oxidation to COG have been mostly catalytic $[10,50,51,53,78,79]$, with only a few reports on non catalysed partial oxidation [54, 55], mostly related to numerical simulations. Chen et al. [80] performed a theoretic thermodynamic analysis of the partial oxidation of cold preconditioned COG to study the influence of two critical parameters on conversions and yields: temperature (studied in the interval from 500 to $1750{ }^{\circ} \mathrm{C}$ ) and $\mathrm{O}_{2} / \mathrm{CH}_{4}$ molar ratio (studied in the interval from 0.25 to 1 ). They also studied the possibility of adding an additional step to the process, a WGS reaction of syngas, aiming to increase $\mathrm{H}_{2}$ yield. The optimal operating conditions found comprised an $\mathrm{O}_{2} / \mathrm{CH}_{4}$ molar ratio of 0.5 and temperatures higher than $1000^{\circ} \mathrm{C}$. Under these conditions, carbon deposition was negligible [80]. A related thermodynamic study reached almost the same conclusions, (namely an ideal $\mathrm{O}_{2} / \mathrm{CH}_{4}$ molar ratio in the range of $0.46-0.47$ ), but suggested temperatures could be reduced to $800-900^{\circ} \mathrm{C}$ for a carbon deposition-free process [81].

A deep analysis of the influence of different reaction conditions on the final syngas produced using $\mathrm{Ni} / \mathrm{SiO}_{2}$ catalysts indicated that oxygen was completely consumed at temperatures from 600 to $900{ }^{\circ} \mathrm{C}$, and $\mathrm{H}_{2}$ and $\mathrm{CO}$ selectivities increased $\left(\mathrm{H}_{2} / \mathrm{CO}\right.$ ratio decreased) at increased temperatures [9]. This behavior was claimed to be influenced by methane combustion at low temperatures, whereas partial oxidation processes prevailed at high temperatures. The influence of $\mathrm{O}_{2} / \mathrm{CH}_{4}$ ratio was also studied and shown to be of critical importance in the process [80]. Conversion increased dramatically when $\mathrm{O}_{2} / \mathrm{CH}_{4}$ ratio was increased from 0.125 to 1.0 at a temperature of $750{ }^{\circ} \mathrm{C}$. Selectivities to $\mathrm{H}_{2}$ and $\mathrm{CO}$ decreased at $\mathrm{O}_{2} / \mathrm{CH}_{4}$ ratios higher than 0.5 . The authors suggested that these results were a consequence of the consumption of the surplus of oxygen in the complete oxidation of methane (reaction 8) and/or the complete oxidation of the produced $\mathrm{H}_{2}$ and CO (reactions 9 and 10): 
$\mathrm{H}_{2}+1 / 2 \mathrm{O} 2 \leftrightarrow \mathrm{H}_{2} \mathrm{O}$

(reaction 9)

$\mathrm{CO}+1 / 2 \mathrm{O}_{2} \leftrightarrow \mathrm{CO}_{2}$

(reaction 10)

An increase in space velocity favoured the combustion of methane in detriment to partial oxidation. Therefore, the value of the space velocity was suggested to play an important role in order to be able to treat as much gas as possible while avoiding high rates of methane combustion, which will lead to a lower selectivity.

One of the most important issues in the industrial implementation of partial oxidation technologies relates to its elevated cost (in both economic and energetic terms) to supply pure oxygen to carry out the reaction. In fact, as much as $40 \%$ of the expenses of a partial oxidation plant come from oxygen production processes [82]. To overcome this problem, the use of membrane reactors has become an attractive alternative to conventional technologies. In the particular case of COG partial oxidation, membrane reactors have been pretty much the only technology to be investigated in recent years $[10,39,50,51,53,78,79,81,83]$. These reactors offer the possibility to feed air directly instead of the need for previous separation processes to feed pure oxygen. Inside the reactor, an oxygen permeable membrane exclusively allows oxygen to reach the catalyst, but not the other components present in the air. A scheme of this system is shown in Figure 3. This technology has shown promising results to date, with yields, conversions and selectivities being as high as those reported using the conventional technology. It can therefore be considered as a potential future alternative for syngas production from COG valorisation [10,78, 81, 83]. The presence of other species different from methane influences the performance of the membrane in terms of stability and oxygen flux. Hydrogen is a particularly interesting compound which behaves as a "pseudo-catalyst" and favours the oxygen permeation through the membrane when BCFNO membranes (composed of $\mathrm{Ba}, \mathrm{Co}, \mathrm{Fe}, \mathrm{Nb}$ and $\mathrm{O}$ ) are employed [84]. These membranes also show excellent long-term stability. In the light of these premises, research into this type of membrane technologies and reactors for the partial oxidation of COG are likely to take over during the next few years. In fact, such technology has also been applied to hot COG and results were even more interesting to those of cold preconditioned COG [52]. Quantitative conversions could be achieved for heavy components (e.g. toluene) at methane conversions higher than 90\% [52]. 


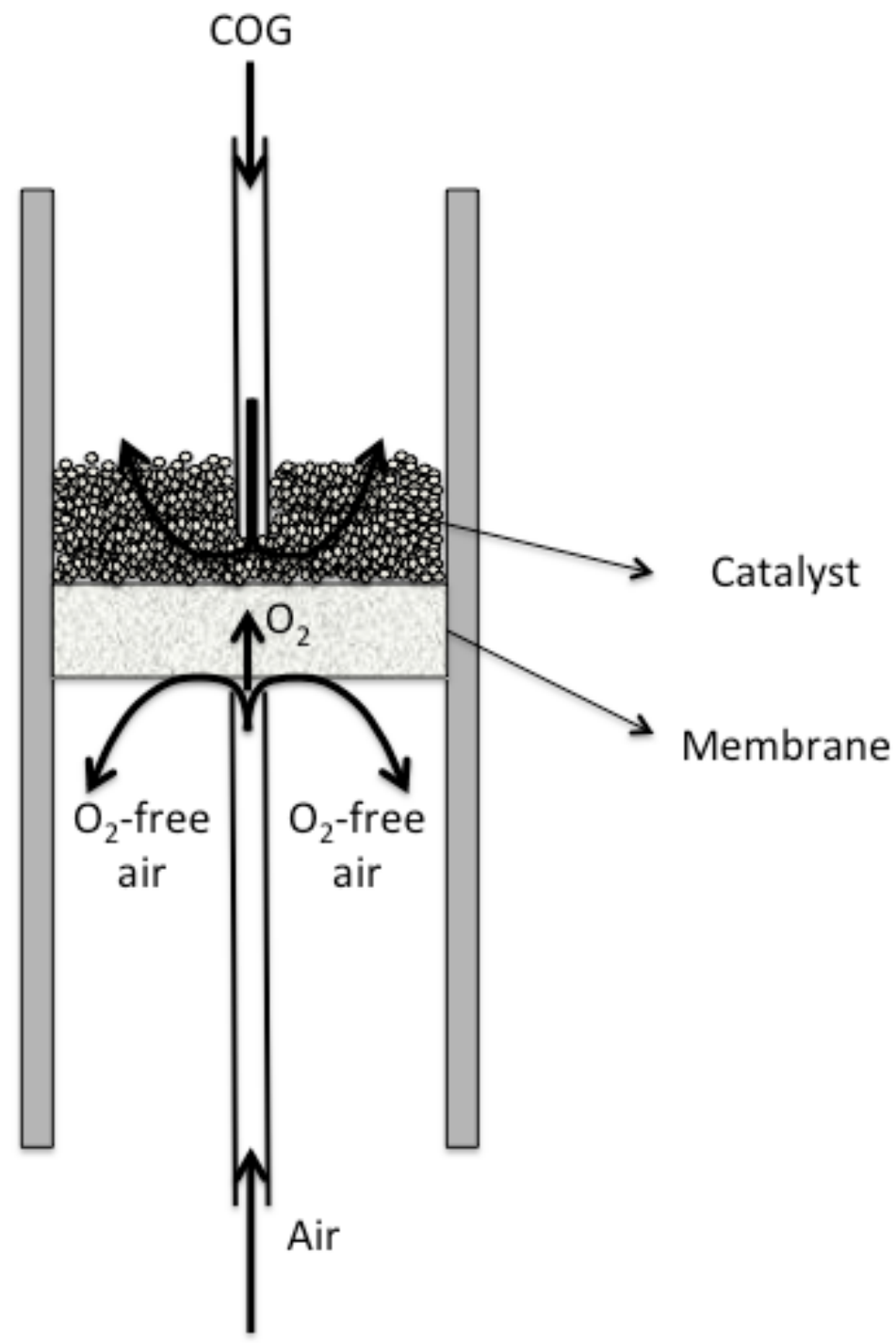

Fig. 3. Scheme of a membrane reactor for the partial oxidation of coke oven gas.

\subsection{Methanol production}

Most of the published works on the transformation of COG into syngas focused on the final production of hydrogen. However, an interesting alternative reported in some work deals with the use of COG-derived syngas for the synthesis of organic chemicals including methanol. The production of methanol from COG-derived syngas has been widely investigated due to its practicality in obtaining a liquid fuel instead of a gaseous product $[40-42,46,85,86]$ as well as to the recent interest in methanol over the past years [2]. Methanol has been proposed to potentially play a key role in the future energetic model as a raw material for biofuels production of biofuels and/or hydrogen carrier in 
the Hydrogen Economy. Indeed it has acquired so much importance that the Nobel Prize winner, Prof. Geroge A. Olah, has proposed Methanol Economy as an alternative to Hydrogen Economy [87, 88].

In the case of COG, the most evident example of the increased interest in methanol production from COG is the construction of several industrial plants in China to manufacture 1.2 million ton/year of methanol from COG, China being world leader in coke production (and therefore COG) [89].

COG dry reforming can be considered as the most interesting syngas production technology for methanol synthesis due to the possibility to obtain an optimum $\mathrm{H}_{2} / \mathrm{CO}$ ratio of 2 in just one step (without the need for any preconditioning stage), as long as such dry reforming is conducted under stoichiometric conditions of $\mathrm{CH}_{4}$ and $\mathrm{CO}_{2}$ [4042,47]. Moreover, the process also involves a partial recycling of the $\mathrm{CO}_{2}$ (Figure 4) [40-42], as half of the $\mathrm{CO}_{2}$ produced upon methanol consumption is recycled in the dry reforming process.

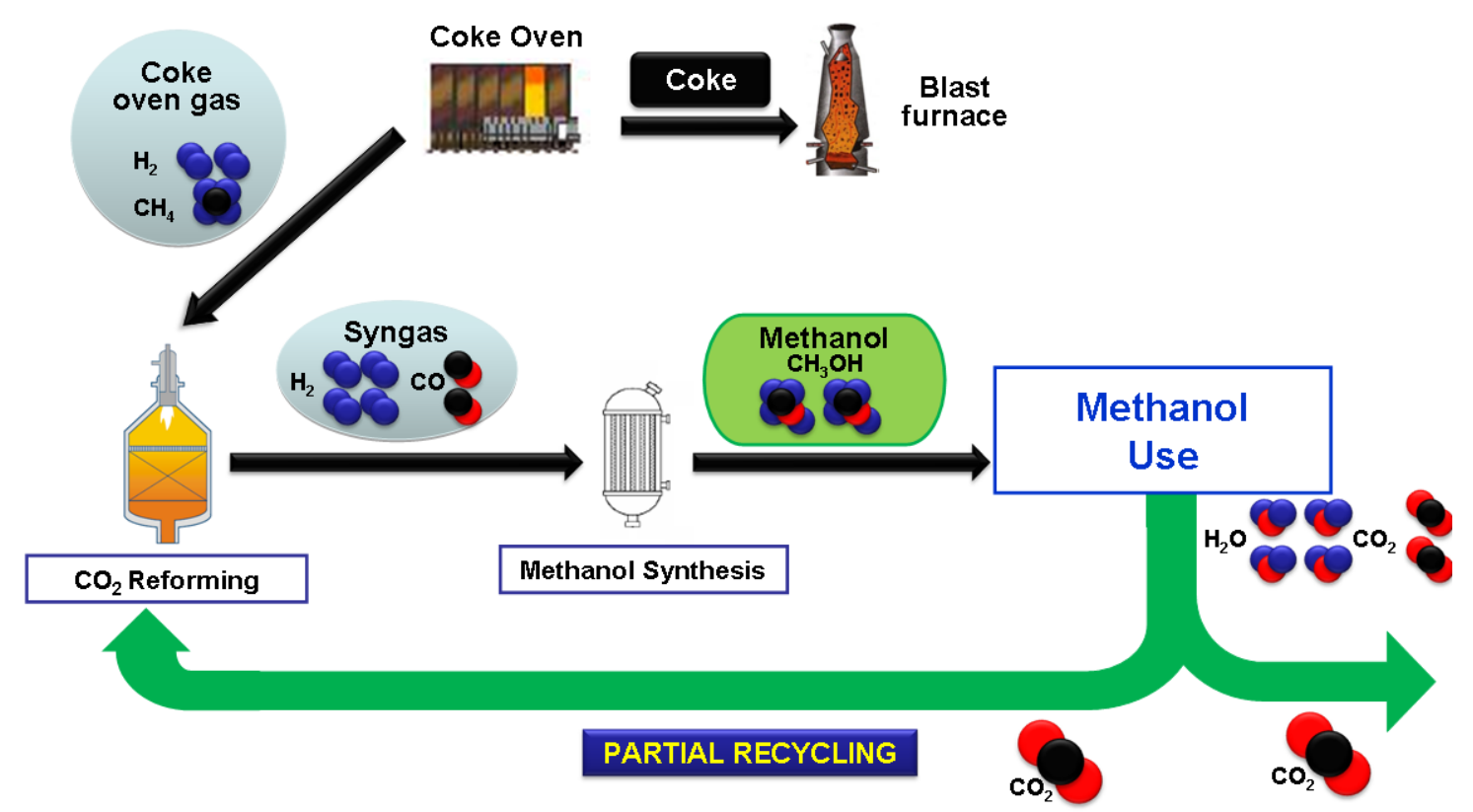

Fig. 4. Partial recycling of $\mathrm{CO}_{2}$ in the dry reforming of coke oven gas to produce methanol for energy generation.

There are two reactions taking place in the synthesis of methanol (Reaction 11 and Reaction 12). 
$2 \mathrm{H}_{2}+\mathrm{CO} \leftrightarrow \mathrm{CH}_{3} \mathrm{OH}$

(reaction 11)

$3 \mathrm{H}_{2}+\mathrm{CO}_{2} \leftrightarrow \mathrm{CH}_{3} \mathrm{OH}+\mathrm{H}_{2} \mathrm{O}$

(reaction 12)

The presence of Reaction 12 imposes an additional restriction to that of $\mathrm{H}_{2} / \mathrm{CO}$ ratio, as represented in Equation $1[31,46,87,88,90-93]$. The optimal ratio for the $\mathrm{R}$ parameter has been established to being the 2.03-2.05 range [88-93].

$\mathrm{R}=\left(\mathrm{H}_{2}-\mathrm{CO}_{2}\right) /\left(\mathrm{CO}+\mathrm{CO}_{2}\right)$

(Equation 1)

This $\mathrm{R}$ parameter gives values slightly lower than 2 when COG-derived syngas is produced by means of dry reforming [40-42]. However, as conversions in methanol synthesis are very low, the gas purge in the recycling loop that needs to be included in the process $[31,90]$, gives rise to a hydrogen-rich gas, which can be recovered and used as fuel for the plant or to adjust the value of the $\mathrm{R}$ parameter [90]. A detailed thermodynamic analysis of this process was carried out by our research group [94]. Results showed that it is possible to obtain $\mathrm{H}_{2} / \mathrm{CO}$ ratios very close to 2 and $\mathrm{R}$ parameter values slightly lower than 2, at high conversions and selectivities, working at temperatures higher than $800{ }^{\circ} \mathrm{C}$ and under stoichiometric conditions of $\mathrm{CH}_{4}$ and $\mathrm{CO}_{2}$ [94].

Further techno-economic studies of methanol production from COG in a Swedish plant show that this can be economically competitive with other methanol production technologies and, annual production could meet as much as $58 \%$ of the methanol demand in the region where the plant is situated [86].

Maruoka and Akiyama [85] also studied the potential of methanol production from $\mathrm{COG}$, in this case, from the exergetic point of view. They proposed an energetic integration, using the latent heat from the exhaust gases from the LD converter of the steel mill, in the reforming process of COG to produce syngas for methanol synthesis. Methanol could be produced with only $28 \%$ of the total exergy loss experienced by the conventional methanol production process. 


\section{Other Technologies}

The feasibility of the aforementioned technologies has been demonstrated by their already existing applications in current industrial plants [8,89]. Interestingly, there are other emerging technologies that could become important alternatives in the near future.

For example, the chemical looping combustion (CLC) of $\mathrm{COG}$, with the objective to improve combustion efficiency and facilitating the capture of the $\mathrm{CO}_{2}$ produced in the system has been proposed [95]. This technology is an elegant and energy efficient method to capture $\mathrm{CO}_{2}$ from fuels combustion. It consists of two reactors and a circulating metal oxide that works as oxygen carrier (Figure 5). The metal oxide is reduced in the fuel reactor, then circulates to the air reactor where it is oxidised to its initial state. In this process, $\mathrm{H}_{2} \mathrm{O}$ and $\mathrm{CO}_{2}$ are the only combustion products and $\mathrm{CO}_{2}$ is easier to capture as these products are not diluted with $\mathrm{N}_{2}$ from air.

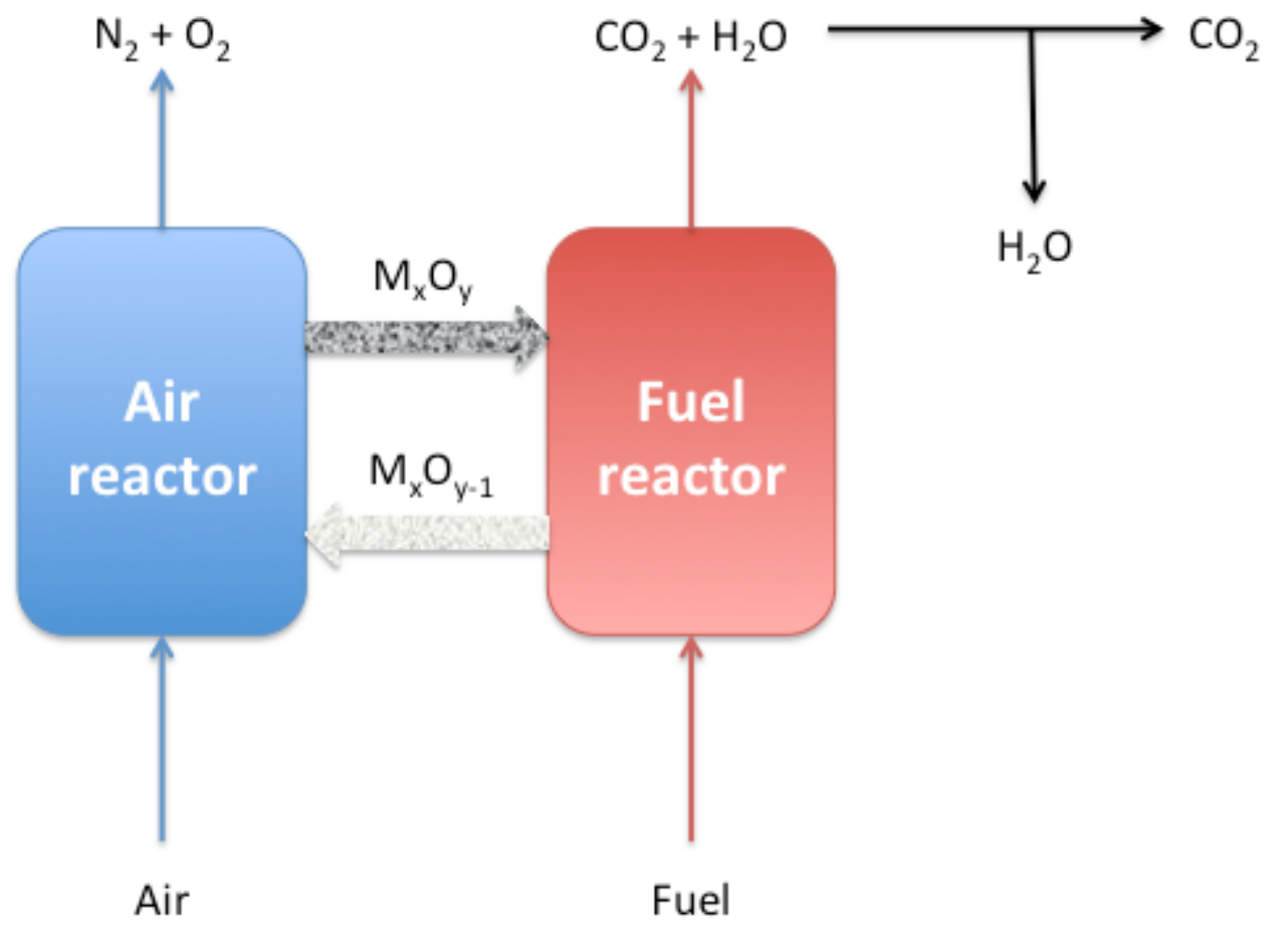

Fig. 5. Scheme of the process of chemical looping combustion. 
In this work, different oxygen carriers were studied, the best results being obtained with that comprising $45 \%$ of $\mathrm{Fe}_{2} \mathrm{O}_{3}, 15 \%$ of $\mathrm{CuO}$ and $40 \%$ of $\mathrm{MgAl}_{2} \mathrm{O}_{4}$. This carrier showed a high and stable activity over 15 reduction-oxidation cycles and achieved a maximum fuel conversion of $92 \%$ [95].

Other systems proposed during recent years are based on the combination of more than one technology. Single technologies will not be able to achieve an optimal utilisation of COG. However, combinations of such systems could possibly produce the needed synergy to improve single technologies. Several authors have recently proposed the combination of these techniques. A system in which PSA-mediated separation of hydrogen was combined with subsequent thermal upgrading of COG to produce syngas (and more $\mathrm{H}_{2}$ ) was recently proposed by Wang et al. [96] This study also included the necessary $\mathrm{CO}_{2}$ adsorption technology to improve hydrogen production. Such combination led to an $\mathrm{H}_{2}$ production increase of about $9 \%$.

Comparatively, Jin et al. [97] proposed a multifunctional energy technology in which COG and coal were utilised to produce hydrogen and energy in the same system. Improved hydrogen recoveries and energy efficiencies at reduced $\mathrm{CO}_{2}$ emissions could be obtained in the combined technology as compared to those of individual systems.

A polygeneration system in which three different chemicals (methanol, dimethyl ether and dimethyl carbonate) were produced from COG and coal gasification gas by means of an integrated catalytic synthesis procedure was also recently reported [98]. A simulation of the proposed system (with comments on improvements needed in syngas conversion and reformer design) was also included as part of this work to demonstrate the potential of the technology to efficiently produce high added value chemicals.

\section{Future prospects and outlook}

The steelmaking industry is the largest energy consuming manufacturing sector in the world and, therefore, it is responsible for 5-7\% of the total anthropogenic $\mathrm{CO}_{2}$ emissions. Consequently, it is necessary for this industry to achieve the highest possible energetic efficiency and to reduce GHG emissions. A point of high interest for this purpose is coke oven gas (COG). Although this gas is used as fuel in different processes 
of the steelmaking plants, there is an important surplus, which needs to be treated in order to obtain a better energetic efficiency, diminish GHG emissions and achieve higher economic benefits.

During recent years, alternative technologies for exploiting the COG surplus have attracted much attention due to the environmental, energetic and economical benefits that can be obtained from them. Table 3 summarizes the main advantages and disadvantages of all the technologies reviewed in this work. These alternatives can be divided in three main blocks: hydrogen separation, synthesis gas production and other technologies. Hydrogen separation has a huge potential since $\mathrm{COG}$ is a $\mathrm{H}_{2}$-rich gas, which would allow a "green" production of $\mathrm{H}_{2}$, since, instead of the pollution and GHG emissions characteristic of conventional $\mathrm{H}_{2}$ production technologies, using $\mathrm{COG}$ as $\mathrm{H}_{2}$ source, would eliminate the pollution resulting from its combustion. Hydrogen separation has been one of the most studied alternatives for using the COG surplus. Moreover, some of these technologies, such as PSA and membrane separation are already in use in other industrial processes, so their implantation in coking plants would not present any special difficulty. However, the $\mathrm{H}_{2}$ recovery from COG surplus has an important drawback that needs to be overcome. With these technologies, no advantage is taken of the other gases, especially those containing carbon, i.e. $\mathrm{CH}_{4}, \mathrm{CO}, \mathrm{CO}_{2}$ and light hydrocarbons. For this reason, $\mathrm{H}_{2}$ separation needs to be combined with other technologies in order to exploit all of the components of the COG surplus.

For syngas production, COG is upgraded by means of the different technologies currently available (steam reforming, dry reforming and partial oxidation), making these processes interesting alternatives for $\mathrm{H}_{2}$ amplification of the original COG or for the production of chemicals, thereby supplanting conventional production from natural gas or petroleum. Synthesis gas production from COG surplus seems to be the most interesting alternative for the use of this interesting source. The large number of processes available (steam reforming, dry reforming, partial oxidation) allows obtaining a wide variety of $\mathrm{H}_{2} / \mathrm{CO}$ ratios (from 2 in dry reforming to nearly 5 in steam reforming), making the COG alternative highly versatile for obtaining different final chemical products. Moreover, even for the production of $\mathrm{H}_{2}, \mathrm{COG}$ is a more interesting alternative than $\mathrm{H}_{2}$ separation, since the hydrocarbons $\left(\mathrm{CH}_{4}\right.$ and $\left.\mathrm{C}_{\mathrm{n}} \mathrm{H}_{\mathrm{m}}\right)$ are also used. However, reforming processes are energy intense technologies, so their industrial 
implantation needs to study in depth the energetic requirements and benefits. Besides, the construction of reforming plants requires a high level of capital investments.

Special attention has been paid to methanol production, due to the interest of this product as a gasoline substitute or $\mathrm{H}_{2}$ carrier. In this case, dry reforming of COG seems to be the preferable technology, since it will require fewer process units than the other thermal upgrading technologies. In the particular case of methanol, it is already industrially implanted and. Besides, by using dry reforming as the method for the production of synthesis gas, it will be possible to partially recycle the $\mathrm{CO}_{2}$ produced when methanol has been consumed. Moreover, the economic studies carried out on this matter, suggest that it would be economically competitive with classical methanol synthesis processes. Even so, the complete process of methanol production will require a higher level of investment and more complex facilities.

Other interesting alternatives, such as COG chemical looping combustion or the combination of two or more of the previous technologies have been proposed, though research into these systems is still in its initial stages and will need further research before considering their implantation at industrial level. 
Table 3. Advantages and disadvantages of the different technologies for COG use.

\begin{tabular}{|c|c|c|c|c|c|c|}
\hline Process & Technology & & Advantages & \multicolumn{3}{|c|}{ Disadvantages } \\
\hline \multirow{4}{*}{$\begin{array}{l}\text { Hydrogen } \\
\text { separation }\end{array}$} & PSA & $\begin{array}{l}\text { - Well developed } \\
\text { - Easy industrial } \\
\text { implementation } \\
\end{array}$ & $\begin{array}{l}\text { - Low energy requirement } \\
\text { - Low operating cost } \\
\text { - High } \mathrm{H}_{2} \text { purity } \\
\end{array}$ & \multirow{4}{*}{$\begin{array}{l}\text { - Need of other } \\
\text { technologies for } \\
\text { whole exploitation of } \\
\text { COG surplus }\end{array}$} & \multicolumn{2}{|c|}{$\begin{array}{l}\text { - Previous separation of tar, BTX, } \mathrm{H}_{2} \mathrm{~S}, \mathrm{NH}_{3} \text { and light } \\
\text { hydrocarbons }\end{array}$} \\
\hline & Membranes & $\begin{array}{l}\text { - Well developed } \\
\text { - Easy industrial } \\
\text { implementation }\end{array}$ & $\begin{array}{l}\text { - Easy operation } \\
\text { - Low capital and operating costs } \\
\text { - Low energy requirement }\end{array}$ & & \multicolumn{2}{|c|}{$\begin{array}{l}\text { - } \mathrm{H}_{2} \text { purity limited to } 95 \% \\
\text { - Less studied for } \mathrm{H}_{2} \text { separation from } \mathrm{COG}\end{array}$} \\
\hline & Hydrates & $\begin{array}{l}\text { - Mild operating } \\
\text { conditions }\end{array}$ & $\begin{array}{l}\text { - No need of removing light } \\
\text { hydrocarbons }\end{array}$ & & \multicolumn{2}{|c|}{$\begin{array}{l}\text { - Low stage of development } \\
\text { - Low } \mathrm{H}_{2} \text { concentration } \\
\text { - Needs additives }\end{array}$} \\
\hline & Cryogenic & \multicolumn{2}{|l|}{ - High purity of $\mathrm{H}_{2}$} & & - Complicated process & - Low stage of development \\
\hline \multirow{4}{*}{$\begin{array}{l}\text { Syngas } \\
\text { Production }\end{array}$} & $\begin{array}{l}\text { Steam } \\
\text { reforming }\end{array}$ & \multirow{4}{*}{$\begin{array}{l}\text { - Lower } \mathrm{CO} 2 \text { emissions } \\
\text { than conventional } \\
\text { processes } \\
\text { - Whole exploitation of } \\
\text { COG surplus } \\
\text { - High versatility for the } \\
\text { production of } \\
\text { chemicals }\end{array}$} & $\begin{array}{l}\text { - Most used and known technology } \\
\text { - Catalysts well developed } \\
\text { - High } \mathrm{H}_{2} / \mathrm{CO} \text { ratio } \\
\text { - Possible use of hot COG (but quick } \\
\text { catalyst deactivation) }\end{array}$ & \multirow{4}{*}{$\begin{array}{l}\text { - High energy } \\
\text { requirements } \\
\text { - High operation and } \\
\text { capital costs }\end{array}$} & \multicolumn{2}{|c|}{$\begin{array}{l}\text { - The high } \mathrm{H}_{2} \mathrm{O} / \mathrm{CH}_{4} \text { ratios avoiding catalyst } \\
\text { deactivation decrease energy efficiency } \\
\text { - Mild pressures } \\
\text { - With cold } \mathrm{COG} \text { the complete elimination of BTX, } \\
\mathrm{NH}_{3} \text { and } \mathrm{H}_{2} \mathrm{~S} \text { is needed }\end{array}$} \\
\hline & Dry reforming & & $\begin{array}{l}\text { - Requires lower pressure and energy } \\
\text { - Consumption of } \mathrm{CO}_{2} \\
\text { - } \mathrm{H}_{2} / \mathrm{CO} \approx 2 \text { (Fischer Tropsch) } \\
\text { - Possible to avoid total } \mathrm{H}_{2} \mathrm{~S} \text { elimination } \\
\end{array}$ & & \multicolumn{2}{|c|}{$\begin{array}{l}\text { - Needs complete elimination of BTX and } \mathrm{NH}_{3} \\
\text { - No commercial catalyst }\end{array}$} \\
\hline & $\begin{array}{l}\text { Partial } \\
\text { oxidation }\end{array}$ & & $\begin{array}{l}\text { - High energy efficiency } \\
\text { - Higher reaction rates } \\
\text { - Possible use of hot COG (but quick } \\
\text { catalyst deactivation) }\end{array}$ & & \multicolumn{2}{|c|}{$\begin{array}{l}\text { - Cold COG needs complete elimination of BTX, } \\
\mathrm{NH}_{3} \text { and } \mathrm{H}_{2} \mathrm{~S} \\
\text { - High temperatures } \\
\text { - High costs (reduced with membrane technology) } \\
\text { - Low operation margin in the } \mathrm{O}_{2} / \mathrm{CH}_{4} \text { ratio }\end{array}$} \\
\hline & $\begin{array}{l}\text { Methanol } \\
\text { production }\end{array}$ & & $\begin{array}{l}\text { - Possible partial recycling of } \mathrm{CO}_{2} \\
\text { - Industrially implanted } \\
\text { - Economically competitive } \\
\text { - Easier to handle than } \mathrm{H}_{2}\end{array}$ & & \multicolumn{2}{|c|}{$\begin{array}{l}\text { - Recovery of unreacted } \mathrm{H}_{2} \text { to adjust the } \mathrm{H}_{2} / \mathrm{CO} \text { ratio } \\
\text { - Higher cost and more complex facilities }\end{array}$} \\
\hline \multirow{2}{*}{$\begin{array}{l}\text { Other } \\
\text { technologies }\end{array}$} & $\begin{array}{l}\text { Chemical } \\
\text { Looping }\end{array}$ & \multicolumn{2}{|c|}{ - Easier CO2 capture } & \multirow{2}{*}{\multicolumn{3}{|c|}{ - Low stage of developement }} \\
\hline & Combination & \multicolumn{2}{|c|}{ - Optimal use of COG surplus } & & & \\
\hline
\end{tabular}




\section{Acknowledgments}

JMB acknowledges the support received from the CSIC JAE Program. Financial support from the PCTI Asturias (Projects PEST08-03 and PEST08-21) is also acknowledged. Rafael Luque gratefully acknowledges support from the Spanish MICINN via the concession of a Ramon y Cajal contract (ref. RYC-2009-04199) and funding under projects P10-FQM-6711 (Consejeria de Ciencia e Innovacion, Junta de Andalucia) and CTQ2011 28954-C02-02 (MICINN).

\section{References}

[1] J.-P. Birat, The challenge of Global Warming to the Steel Industry, a European viewpoint, in: IRSID (Ed.), Maizières-lès-Metz, France, 2002.

[2] C. Wang, M. Larsson, C. Ryman, C.E. Grip, J.O. Wikström, A. Johnsson, J. Engdahl, A model on $\mathrm{CO} 2$ emission reduction in integrated steelmaking by optimization methods, International Journal of Energy Research, 32 (2008) 1092-1106.

[3] P. Diemer, H.J. Killich, K. Knop, H.B. Lüngen, M. Reinko, P. Schmöle, Potentials for utilization of coke oven gas in integrated iron and steel works, in: 2nd International Meeting on Ironmaking and 1st International Symposium on Iron Ore and Parallel Event- 5th Japan-Brazil Symposium on Dust Processing-Energy-Environment on Metallurgical Industries, 2004, pp. 433-446.

[4] M. Modesto, S.A. Nebra, Exergoeconomic analysis of the power generation system using blast furnace and coke oven gas in a Brazilian steel mill, Applied Thermal Engineering, 29 (2009) 2127-2136.

[5] M.T. Johansson, M. Söderström, Options for the Swedish steel industry - Energy efficiency measures and fuel conversion, Energy, 36 (2011) 191-198.

[6] T. Matsumiya, Steelmaking technology for a sustainable society, Calphad: Computer Coupling of Phase Diagrams and Thermochemistry, (2011). 
[7] F. Joseck, M. Wang, Y. Wu, Potential energy and greenhouse gas emission effects of hydrogen production from coke oven gas in U.S. steel mills, Int J Hydrogen Energy, 33 (2008) 1445-1454.

[8] S. Richlen, Using coke oven gas in a blast furnace saves over $6 \$$ million anually at a steel mill, in: O.o.I.T.E.E.a.R. Energy (Ed.), U.S. Department of Energy, Washington, 2000 .

[9] J. Guo, Z. Hou, J. Gao, X. Zheng, Production of syngas via partial oxidation and CO2 reforming of coke oven gas over a Ni catalyst, Energy Fuels, 22 (2008) 14441448 .

[10] Z. Yang, W. Ding, Y. Zhang, X. Lu, Y. Zhang, P. Shen, Catalytic partial oxidation of coke oven gas to syngas in an oxygen permeation membrane reactor combined with $\mathrm{NiO} / \mathrm{MgO}$ catalyst, Int J Hydrogen Energy, 35 (2010) 6239-6247.

[11] J. Shen, Z.Z. Wang, H.W. Yang, R.S. Yao, A new technology for producing hydrogen and adjustable ratio syngas from coke ove gas, Energy Fuels, 21 (2007) 35883592 .

[12] IEA, CO2 Emissions from Fuel Combustion 2012, in, International Energy Agency, 2012.

[13] J.M. Bermúdez, B. Fidalgo, A. Arenillas, J.A. Menéndez, CO 2 reforming of coke oven gas over a Ni/ $\gamma \mathrm{Al} 2 \mathrm{O} 3$ catalyst to produce syngas for methanol synthesis, Fuel, 94 (2012) 197-203.

[14] H. Brueggendick, E. Richter, K. Knoblauch, H. Juentgen, Modelling of adsorption in cyclic operation of a PSA plant for $\mathrm{H} 2$ recovery, Chemical Engineering and Technology, 10 (1987) 390-398.

[15] K. Yabumoto, T. Asai, S. Uchida, K. Ohhigashi, NEW PROCESS FOR COPRODUCTION OF SNG AND H//2 FROM COG, Sumitomo Metals, 39 (1987) 21-26. 
[16] T. Otowa, A. Shiraki, Y. Ishigaki, S. Nishida, Methane adsorption as a calorie upgrading PSA in the SNG process, Gas Separation and Purification, 3 (1989) 139-142.

[17] H.J. Schröter, Carbon molecular sieves for gas separation processes, Gas Separation and Purification, 7 (1993) 247-251.

[18] J. Yang, C.H. Lee, Adsorption dynamics of a layered bed PSA for H2 recovery from coke oven gas, AIChE J, 44 (1998) 1325-1334.

[19] J. Yang, C.H. Lee, J.W. Chang, Separation of Hydrogen Mixtures by a Two-Bed Pressure Swing Adsorption Process Using Zeolite 5A, Ind Eng Chem Res, 36 (1997) 2789-2798.

[20] H. Ahn, C.H.A. Lee, B. Seo, J. Yang, K. Baek, Backfill cycle of a layered bed H2 PSA process, Adsorption, 5 (1999) 419-433.

[21] C.H. Lee, J. Yang, H. Ahn, Effects of carbon-to-zeolite ratio on layered bed H2 PSA for coke oven gas, AIChE J, 45 (1999) 535-545.

[22] H. Ahn, J. Yang, C.H. Lee, Effects of feed composition of coke oven gas on a layered bed H2 PSA process, Adsorption, 7 (2001) 339-356.

[23] J.J. Hwang, W.R. Chang, Life-cycle analysis of greenhouse gas emission and energy efficiency of hydrogen fuel cell scooters, Int J Hydrogen Energy, 35 (2010) 11947-11956.

[24] F.G. Wiessner, Basics and industrial applications of pressure swing adsorption (PSA), the modern way to separate gas, Gas Separation and Purification, 2 (1988) 115119.

[25] R.H. Perry, D.W. Green, Perry's Chemical Engineers' Handbook, 7th ed. ed., USA, 1999. 
[26] P. Bernardo, E. Drioli, G. Golemme, Membrane gas separation: A review/state of the art, Ind Eng Chem Res, 48 (2009) 4638-4663.

[27] R. Baker, Membrane technology and applications, Wiley, 2004.

[28] K. Chang, Q. Li, Q. Li. Refrigeration cycle for cryogenic separation of hydrogen from coke oven gas. Frontiers Energy Power Eng China, 2 (2008) 484-488.

[29] Q. Sung, J. Dong, X. Guo, A. Liu, J. Zhang. Recovery of hydrogen from coke-oven gas by forming hydrate. Ind Eng Chem Res, 51 (2012) 6205-6211.

[30] P. Englezos. Clathrate hydrates. Ind Eng Chem Res, 32 (1992) 1251-1274

[31] I. Wender, Reactions of synthesis gas, Fuel Process Technol, 48 (1996) 189-297.

[32] A. van der Drift, H. Boerrigter, Synthesis gas from biomass for fuels and chemicals, IEA bioenergy agreement task 33: thermal gasification of biomass, in: I.E. Agency (Ed.), Stockholm, Sweden, 2006.

[33] A. Domínguez, Y. Fernández, B. Fidalgo, J.J. Pis, J.A. Menéndez, Biogas to syngas by microwave-assisted dry reforming in the presence of char, Energy Fuels, 21 (2007) 2066-2071.

[34] A. Jess, Catalytic upgrading of tarry fuel gases: A kinetic study with model components, Chemical Engineering and Processing: Process Intensification, 35 (1996) 487-494.

[35] K. Miura, M. Kawase, H. Nakagawa, R. Ashida, T. Nakai, T. Ishikawa, Conversion of tar in hot coke oven gas by pyrolysis and steam reforming, Journal of Chemical Engineering of Japan, 36 (2003) 735-741.

[36] T. Hashimoto, M. Onozaki, Reforming of hot coke oven gas, Nihon Enerugi Gakkaishi/Journal of the Japan Institute of Energy, 85 (2006) 364-370. 
[37] M. Onozaki, K. Watanabe, T. Hashimoto, H. Saegusa, Y. Katayama, Hydrogen production by the partial oxidation and steam reforming of tar from hot coke oven gas, Fuel, 85 (2006) 143-149.

[38] J.Y. Zhang, J.M. Zhou, H.J. Yan, Kinetic model on coke oven gas with steam reforming, Journal of Central South University of Technology (English Edition), 15 (2008) 127-131.

[39] H. Cheng, B. Yue, X. Wang, X. Lu, W. Ding, Hydrogen production from simulated hot coke oven gas by catalytic reforming over $\mathrm{Ni} / \mathrm{Mg}(\mathrm{Al}) \mathrm{O}$ catalysts, Journal of Natural Gas Chemistry, 18 (2009) 225-231.

[40] J.M. Bermúdez, A. Arenillas, J.A. Menéndez, Syngas from CO2 reforming of coke oven gas: Synergetic effect of activated carbon/Ni- $\gamma \mathrm{Al} 2 \mathrm{O} 3$ catalyst, Int J Hydrogen Energy, 36 (2011) 13361-13368.

[41] J.M. Bermúdez, B. Fidalgo, A. Arenillas, J.A. Menéndez, CO2 reforming of coke oven gas over a Ni/ $\gamma \mathrm{A} 12 \mathrm{O} 3$ catalyst to produce syngas for methanol synthesis, Fuel, 94 (2012) 197-203.

[42] J.M. Bermúdez, B. Fidalgo, A. Arenillas, J.A. Menéndez, Dry reforming of coke oven gases over activated carbon to produce syngas for methanol synthesis, Fuel, 89 (2010) 2897-2902.

[43] Z. Yang, Y. Zhang, X. Wang, X. Lu, W. Ding, Steam reforming of coke oven gas for hydrogen production over a $\mathrm{NiO} / \mathrm{MgO}$ solid solution catalyst, Energy Fuels, 24 (2010) 785-788.

[44] B. Yue, X. Wang, X. Ai, J. Yang, L. Li, X. Lu, W. Ding, Catalytic reforming of model tar compounds from hot coke oven gas with low steam/carbon ratio over Ni/MgO-A12O3 catalysts, Fuel Process Technol, 91 (2010) 1098-1104.

[45] J. Zhang, X. Zhang, Z. Chen, L. Li, Thermodynamic and kinetic model of reforming coke-oven gas with steam, Energy, 35 (2010) 3103-3108. 
[46] B. Asp, Biomass- and Coke Oven Gas Based Methanol Production, in: Applied Physics and Mechanical Engineering, Luleå University of Technology, Luleå, 2007.

[47] Y.B. Li, R. Xiao, B. Jin, Thermodynamic equilibrium calculations for the reforming of coke oven gas with gasification gas, Chemical Engineering and Technology, 30 (2007) 91-98.

[48] G. Zhang, Y. Dong, M. Feng, Y. Zhang, W. Zhao, H. Cao, CO2 reforming of CH4 in coke oven gas to syngas over coal char catalyst, Chem Eng J, 156 (2010) 519-523.

[49] L. Li, K. Morishita, T. Takarada, Conversion of hot coke oven gas into light fuel gas over Ni/A12O3 catalyst, Journal of Chemical Engineering of Japan, 39 (2006) 461468.

[50] Y. Zhang, H. Cheng, J. Liu, W. Ding, Performance of a tubular oxygen-permeable membrane reactor for partial oxidation of $\mathrm{CH} 4$ in coke oven gas to syngas, Journal of Natural Gas Chemistry, 19 (2010) 280-283.

[51] H. Cheng, J. Liu, X. Lu, W. Ding, Enhancing the oxygen permeability of BaCo $0.7 \mathrm{Fe} 0.2 \mathrm{Nb} 0.1 \mathrm{O} 3-\delta$ membranes by coating GdBaCo $2-\mathrm{xFe} \mathrm{xO} 5+\delta$ for Partial Oxidation of Coke Oven Gas to Syngas, ACS Applied Materials and Interfaces, 3 (2011) 4032-4039.

[52] H. Cheng, J. Liu, X. Lu, Y. Zhang, W. Ding. Partial oxidation of simulated hot coke oven gases to syngas over $\mathrm{Ru}-\mathrm{Ni} / \mathrm{Mg}(\mathrm{Al}) \mathrm{O}$ catalyst in a ceramic membrane reactor. J Natural Gas Chem, 18 (2009)467-473.

[53] D. Hu, X. Lu, H. Cheng, W. Ding, Catalytic partial oxidation of coke oven gas to syngas over $\mathrm{Ni} / \mathrm{SiO} 2$ catalyst modified by rare earth metal oxide in a membrane reactor, in, 2011, pp. 1024-1028. 
[54] K. Norinaga, J.I. Hayashi, Numerical simulation of the partial oxidation of hot coke oven gas with a detailed chemical kinetic model, Energy Fuels, 24 (2010) 165172.

[55] K. Norinaga, H. Yatabe, M. Matsuoka, J.I. Hayashi, Application of an existing detailed chemical kinetic model to a practical system of hot coke oven gas reforming by noncatalytic partial oxidation, Ind Eng Chem Res, 49 (2010) 10565-10571.

[56] E. Turpeinen, R. Raudaskoski, E. Pongrácz, R.L. Keiski, Thermodynamic analysis of conversion of alternative hydrocarbon-based feedstocks to hydrogen, Int J Hydrogen Energy, 33 (2008) 6635-6643.

[57] J.R. Rostrup-Nielsen, Catalytic Steam Reforming, Catalysis: Science and Technology, 5 (1984) 1-117.

[58] N. Muradov, K. Ramasamy, C. Linkous, C. Huang, I. Adebiyi, F. Smith, A. TRaissi, J. Stevens, Combined pre-reforming-desulfurization of high-sulfur fuels for distributed hydrogen applications, Fuel, 89 (2010) 1221-1229.

[59] H.C. Dibbern, P. Olesen, J.R. Rostrup-Nielsen, P.B. Tottrup, N.R. Udengaard. Make low $\mathrm{H}_{2} / \mathrm{CO}$ syngas using sulphur passivated reforming, Hydrocarbon Process. 65 (1986) 71-74

[60] N.R. Udengaard, J.H.B. Hansen, D.C. Hanson, J.A. Stal. Sulphur passivated reforming process lowers syngas $\mathrm{H}_{2} / \mathrm{CO}$ ratio. Oil Gas J. 90 (1992) 62-67

[61] J. Xu, G.F. Froment, Methane steam reforming, methanation and water-gas shift: I. Intrinsic kinetics, AIChE J, 35 (1989) 88-96.

[62] J.N. Armor, The multiple roles for catalysis in the production of H2, Appl Catal A, 176 (1999) 159-176.

[63] H.C.-o. Group, Hydrogen production and storage. R\&D priorities and gaps, in, International Energy Agency (IEA), Paris (France), 2006. 
[64] M.C.J. Bradford, M.A. Vannice, Catalytic reforming of methane with carbon dioxide over nickel catalysts I. Catalyst characterization and activity, Appl Catal A, 142 (1996) 73-96.

[65] M.C.J. Bradford, M.A. Vannice, Catalytic reforming of methane with carbon dioxide over nickel catalysts II. Reaction kinetics, Appl Catal A, 142 (1996) 97-122.

[66] S. Wang, G.Q. Lu, Reforming of methane with carbon dioxide over Ni/Al2O3 catalysts: Effect of nickel precursor, Appl Catal A, 169 (1998) 271-280.

[67] J.R.H. Ross, Natural gas reforming and CO2 mitigation, Catal Today, 100 (2005) 151-158.

[68] B. Fidalgo, A. Domínguez, J.J. Pis, J.A. Menéndez, Microwave-assisted dry reforming of methane, Int J Hydrogen Energy, 33 (2008) 4337-4344.

[69] B. Fidalgo, L. Zubizarreta, J.M. Bermúdez, A. Arenillas, J.A. Menéndez, Synthesis of carbon-supported nickel catalysts for the dry reforming of $\mathrm{CH} 4$, Fuel Process Technol, 91 (2010) 765-769.

[70] K. Díaz, V. García, J. Matos, Activated carbon supported Ni-Ca: Influence of reaction parameters on activity and stability of catalyst on methane reformation, Fuel, 86 (2007) 1337-1344.

[71] J. Matos, K. Díaz, V. García, T.C. Cordero, J.L. Brito, Methane transformation in presence of carbon dioxide on activated carbon supported nickel-calcium catalysts, Catal Lett, 109 (2006) 163-169.

[72] P. Neumann, S.C. Teuner, F. Von Linde, The Calcor standard and Calcor economy processes, Oil Gas European Magazine, 27 (2001) 44-46. 
[73] B. Fidalgo, A. Arenillas, J.A. Menéndez, Synergetic effect of a mixture of activated carbon $+\mathrm{Ni} / \mathrm{Al} 2 \mathrm{O} 3$ used as catalysts for the $\mathrm{CO} 2$ reforming of $\mathrm{CH} 4$, Appl Catal A, 390 (2010) 78-83.

[74] A.T. Ashcroft, A.K. Cheetham, J.S. Foord, M.L.H. Green, C.P. Grey, A.J. Murrell, P.D.F. Vernon, Selective oxidation of methane to synthesis gas using transition metal catalysts, Nature, 344 (1990) 319-321.

[75] B. Christian Enger, R. Lødeng, A. Holmen, A review of catalytic partial oxidation of methane to synthesis gas with emphasis on reaction mechanisms over transition metal catalysts, Appl Catal A, 346 (2008) 1-27.

[76] M.A. Peña, J.P. Gómez, J.L.G. Fierro, New catalytic routes for syngas and hydrogen production, Appl Catal A, 144 (1996) 7-57.

[77] A.P.E. York, T. Xiao, M.L.H. Green, Brief overview of the partial oxidation of methane to synthesis gas, Topics in Catalysis, 22 (2003) 345-358.

[78] H. Cheng, X. Lu, D. Hu, Y. Zhang, W. Ding, H. Zhao, Hydrogen production by catalytic partial oxidation of coke oven gas in $\mathrm{BaCo} 0.7 \mathrm{Fe} 0.2 \mathrm{Nb} 0.1 \mathrm{O} 3-\delta$ membranes with surface modification, Int J Hydrogen Energy, 36 (2011) 528-538.

[79] H. Cheng, X. Lu, D. Hu, Y. Zhang, W. Ding, Q. Zhong, Improving performance of $\mathrm{BaCo} 0.7 \mathrm{Fe} 0.2 \mathrm{Nb} 0.1 \mathrm{O} 3-\delta$ ceramic membrane by a surface-coating layer for partial oxidation of coke oven gas. Adv. Mat. Res. 154-155 (2011) 877-881.

[80] W.H. Chen, M.R. Lin, T.S. Leu, S.W. Du. An evaluation of hydrogen production from the perspective of using blast furnace and coke oven gas as feedstocks. Int. J. Hydrogen Energy 36 (2011) 11727-11737

[81] Y. Zhang, Q. Li, P. Shen, Y. Liu, Z. Yang, W. Ding, X. Lu, Hydrogen amplification of coke oven gas by reforming of methane in a ceramic membrane reactor, Int J Hydrogen Energy, 33 (2008) 3311-3319. 
[82] J.R. Rostrup-Nielsen. New aspects of syngas production and use. Catal. Today. 63 (2000) 159-164

[83] H. Cheng, X. Lu, Y. Zhang, W. Ding, Hydrogen production by reforming of simulated hot coke oven gas over nickel catalysts promoted with lanthanum and cerium in a membrane reactor, Energy Fuels, 23 (2009) 3119-3125.

[84] Y. Zhang, J. Liu, W. Ding, X. Lu, Performance of an oxygen-permeable membrane reactor for partial oxidation of methane in coke oven gas to syngas, Fuel, 90 (2011) 324-330.

[85] N. Maruoka, T. Akiyama, Exergy recovery from steelmaking off-gas by latent heat storage for methanol production, Energy, 31 (2006) 1632-1642.

[86] J. Lundgren, B. Asp, M. Larsson, C. Grip. Methanol Production at an integrated steel mill. Proceedings of the $.18^{\text {th }}$ International Congress of Chemical and Process Engineering, Prague, Czech Republic, 2008, 24-28

[87] G.A. Olah, After oil and gas: Methanol economy, Catal Lett, 93 (2004) 1-2.

[88] G.A. Olah, A. Goeppert, G.K.S. Prakash, Beyond oil and gas: the methanol economy, Wiley-VCH, Weinheim, Germany, 2006.

[89] Coke Oven gas based methanol production capacity reached 1.2 Mt/a in China, China Petroleum Processing and Petrochemical Technology 4 (2008) 5

[90] K. Aasberg-Petersen, C. Stub Nielsen, I. Dybkjær, J. Perregaard, Large Scale Methanol Production from Natural Gas, in, 2010.

[91] C.N. Hamelinck, A.P.C. Faaij, Future prospects for production of methanol and hydrogen from biomass, in, Universiteit Utrecht, Utrecht, 2001. 
[92] X.M. Liu, G.Q. Lu, Z.F. Yan, J. Beltramini, Recent Advances in Catalysts for Methanol Synthesis via Hydrogenation of CO and CO2, Ind Eng Chem Res, 42 (2003) 6518-6530.

[93] G.J. Tjatjopoulos, I.A. Vasalos, Feasibility Analysis of Ternary Feed Mixtures of Methane with Oxygen, Steam, and Carbon Dioxide for the Production of Methanol Synthesis Gas, Ind Eng Chem Res, 37 (1998) 1410-1421.

[94] J.M. Bermúdez, A. Arenillas, J.A. Menéndez. Equilibrium prediction of $\mathrm{CO}_{2}$ reforming of coke oven gas: suitability for methanol production. Chem. Eng. Sci. 82 (2012) 95-103.

[95] S. Wang, G. Wang, F. Jiang, M. Luo, H. Li, Chemical looping combustion of coke oven gas by using $\mathrm{Fe} 2 \mathrm{O} 3 / \mathrm{CuO}$ with $\mathrm{MgAl} 2 \mathrm{O} 4$ as oxygen carrier, Energy Environ Sci, 3 (2010) 1353-1360.

[96] X. Wang, T. Wang. Hydrogen amplification from coke oven gas using a CO2 adsorption enhanced hydrogen amplification reactor. Int. J. Hydrogen Energy 37 (2012) 4974-4986.

[97] H. Jin, S. Sun, W. Han, L. Gao. Proposal of a novel multifunctional energy system for cogeneration of coke, hydrogen and power. J. Eng. Gas Turbines Power. 131 (2009)

[98] Z. Li, P. Liu, F. He, M. Wang, E.N. Pistikopoulos. Simulation and exergoeconomic analysis of a dual-gas sourced polygeneration process with integrated methanol/DME/DMC catalytic synthesis. Computers Chem. Eng. 35 (2011) 1857-1862 